\title{
CONVERSATIONAL IMPLICATURE APPLIED IN YOUNG LEARNER'S RUMPELSTILTSKIN
}

\author{
Agnes Widyaningrum \\ Faculty of Language and Culture Studies \\ Unisbank, Semarang \\ agnes.maryanto@yahoo.com
}

\begin{abstract}
English children story book is written aimed at boosting their English reader' proficiency as well as their performance in reading. This study is conducted to analyze the conversational implicature recognized in children story book. The object of the study is the story entitled Rumpelstiltskin published by Indian publisher. This study is conducted aimed at finding kinds of conversational implicature recognized in the Young Learner's story book.

Children story book written in English is published to help them learn English. English in Indonesia is as the first foreign language learnt while other countries within Asian continent have English as their second language. TEFL in Indonesia needs more time to make Indonesian students accustomed to use English in their daily conversation.

Book is written in many genres and one of it is narrative. Narrative text type is commonly found in the story therefore the author used their imagination in order to help the readers build their own imagination. Building imagination is part of the activity to help children to be creative. The children are still on their growing period therefore they need many stimulus to help them gain more information stored in their brain.

India is one of Asian's country which English as their second language therefore Indian people speak English better than Indonesian. Though Indian as a country is similar to Indonesia in terms of population but they are more productive in using English. Indonesian people should learn from Indian people in using English since English language is used formally at public places including school. Indian authors are also more productive in writing and one of the writing that I analyze in this study is the children's story belongs to Young Learner's series. I chose Indian book because I believe that children's reader will learn and understand English language easily.
\end{abstract}

Keywords: reading, English story book, conversational implicature

\section{INTRODUCTION}

Reading skill is one of English skills that the students should master. Learning English does not mean that they have to be passive learners on the contrary the students are expected to be active learners. There are many children's story books written in different languages of their own which is aiming at improving students' mastery in reading. One of languages that is well known as international language spoken in the Asian countries is English.

The rise of Asian countries effected some of them implement English as their own second language while Indonesia has another policy that is English is not as the second language but the 
first foreign language. This policy is published by the government because of the nationalism to use our mother tongue. The more people speak in different language the better they will be in learning it. Learning a foreign language is not just for grammar only but it needs practice to be fluent in using it. There is a very famous jargon that is practice makes perfect and it is adopted by linguists to prove their theories.

The students have their own learning style to learn English and one of them is by reading. Reading is an activity to stimulate the students' brain because reading will make the students practice their vocabulary. There are two types of reading for students namely reading aloud and whilst reading. Young learner will have more time for reading aloud because this activity will help them pronounce the English words and improve their vocabulary.

Reading story book is a fun activity for students because they will not learn the story but also the moral value of the story. For example the children's story book written by Indian. In India, English is used as the second language for the educated people therefore there are many English books written by Indian. As one of Asian countries they are quite productive in publishing children's story book written in English. Their books are easy to read and interpret because they are Asian people and most of the stories are similar with Indonesian's children story too.

In order to find out more about the English used in this story book, I as the researcher will try to investigate the conversational implicature implied in this story. The theory used is Grice Maxims for conversational implicature aimed at finding out the kinds of implicature found in this story book.

\section{RESEARCH QUESTION}

There is a problem in this research namely:

a. What is the conversational implicature applied in Young Learner's Rumpelstiltskin based on Grice Maxim theory?

\section{REVIEW OF RELATED LITERATURE}

\section{Previous Study}

In conducting this research I refer to the study conducted by Prilia Kurnia Putri whose thesis writing is under my guidance. She wrote her unpublished thesis entitled Implicature Analysis on Seven Slogan of Isotonic Beverage Product on The Online Advertisement (2018).

\section{Pragmatics}

Some linguists define pragmatics in their own ways among others are definition from Leech (1983:6) who said that pragmatics is the study of meaning related to the speech functions while Yule (1996:3) said that pragmatics is the study of contextual meaning. Those two definitions above mention that pragmatics is the study of meaning and it relates with the context. For example we may use different terms from the same language when we talk to someone who is older or younger than us in certain situation.

Pragmatics as a study has a scope based on Levinson (1995:7) theory who said that pragmatics is the study of deixis, presuppositions, speech act, and aspect of discourse. This means that a word means something differently if it is constructed into a sentence. There is one more 
element belongs to pragmatics area namely implicature. In this study I will use Levinson's theory of pragmatics including implicature as explained below:

a. Deixis

According to Yule (1996:9) deixis is derived from Greek language which means pointing using language. Deixis depends on speaker's meaning. Because it is obviously a form of referring that is tied to the speaker's context, with the most basic distinction between deitic expressions being near speaker versus away speaker. The deixis of the utterance will be meaningful if the context is clearly known.

b. Presuppositions

Based on Yule's idea (1996:25) that presupposition is something that the speaker assumes to be the case prior to making speaker's utterance and not sentences having presuppositions. Presupposition of a statement will remain the same constantly even when the statement is negated. From this definition we can say that speaker's meaning is the focus in this case.

c. Speech act

Austin as written in Levinson (1985:236) said that in uttering a sentence, one might be said to be performing actions. There are three basic acts in saying an utterance those are locutinary act, illocutuinary act and perlocutionary act.

d. Implicature

A proposition has relationship with implicature. By definition what is meant with Implicature is a proposition that is based on the interpretation of the language use and its context of communication in a bound that the participants can interpret the interpretation of an utterance and from what the speakers literally said. This relates with speaker's meaning also because the listener will try to interpret based on the speaker's meaning.

e. Discourse structure

Each utterance and sentence can be analyzed based on the organization of the text. For instance the turn taking system, this system can used to analyze a conversation. Therefore when we analyze a conversation what we are doing is conversational analysis.

\section{Implicature}

A well-known linguist named Grice defined what is implicature. Implicature is what speaker can imply, suggest or mean as distinct from what the speaker literary says (as written in Brown and Yule, 1982:3). This definition is taken based on the verb to imply which means to fold something in something else or finding the meaning from what the speaker's mean. Another scholar, Mey (1993:99) wrote that implicature is something that is implied in conversation which is something implicit in actual use. It states that the listener should find out the literal meaning of the speaker's meaning.

There are two kinds of impliacture based on Grice (as written in Levinson, 1985:126-129) namely:

a. Conventional Implicature.

This type of implicature does not always occur in a conversation. Yule (1996:45) said that conventional implicatures do not have to occur in conversation, and they do not depend on special context for their interpretation. Form definition above we can say that this implicature based on certain convention which is applied in certain condition. 
b. Conversational Implicature

Grice divides conversational implicature into two parts namely:

1. Generalized Conversational Implicature

In this area the knowledge background is not a must to convey the meaning.

2. Personalized Conversational Implicature

This type is opposite to the previous type. This implicature needs a special knowledge background for specific context.

\section{Maxims}

According to Grice (as written in Levinson, 1985:101) there are guidelines to measure whether a conversation is effective or efficient in using the language. The guidelines consist of:

a. The Maxims of Quality

In this maxim saying the truth is a must in this conversation. Grice (in Levinson, 1985:101) said that try to make your own contribution one that is true: (1) do not say what you believe to be false and (ii) do not say that for which you lack of adequate evidence.

b. The Maxims of Quantity

This maxim requires all participants to say something informative to the listener in the conversation.

c. The Maxims of Relevance

In this maxim the speakers must say something that is relevant to what he/she talks about or related to the subject of the conversation.

d. The Maxims of Manner

The participants in this conversation must be saying something orderly and briefly. In this type the participants are not allowed to create something that is ambitious.

\section{Context}

Meaning can be viewed from different angles like from the speaker. Utterances as well as sentences produced by the speaker will create its own context. Levinson (as cited from Prillia in 2017) said that context is important in learning pragmatics because pragmatics is an ability of language users to pair sentences with context in which they would be appropriate (1985:24).

Furthermore another linguist, Leech also wrote that (as cited in Prillia, 2017) context deals with relevant aspects of the physical or social settings of an utterance. He considers context to be any background knowledge assumed to be shared by the speaker and the hearer which contributes hearer's interpretation of what speaker's means by given utterance (1983:24). In addition to what Leech's argue, Parera says that the context is situation formed by setting, activity and relation. The interaction between these three components will form context (1991:120).

Knowing the context of the utterances or sentences will help the hearer to understand the meaning of it because same utterances or sentences spoken or written in different context will yield different meaning. Therefore learning the context will help someone to understand the meaning. Context is divided into the feature and the kinds of it as follows:

a. Features of context

According to Parera (1987) the features of context are setting; activity and relation. Setting is divided into place and time where the situation happens they are: (i) materials components 
around the language interaction; (ii) place is where the communication takes place and (iii) time is time sequence occurs in language interaction. Another component is activity which means that all behavior occurred in language interaction, it covers the language interaction itself, non-verbal interaction, reaction, perception and feeling of the communicator and communicant. The last component is relation. It means the relation among participants which can be identified from the sex, age, social status, etc. (as cited in Prillia, 2017).

b. Kinds of context

There are four kinds of context according to Hasan Lubis (1993, as cited from Prillia, 2017) namely:

1. Physical context

This type of context covers the place where the language is used in communication; the objects presented in the communication and the acts of the communicators and communicants.

2. Linguistic context

It covers speech acts found in the sentences or utterances or certain speech in communication.

3. Social context

This social context means the relation between the communicator and the communicant.

4. Epistemic context

This type of context is about the concept of message found between the communicator and communicant.

\section{RESEARCH METHOD}

\section{Unit of Analysis}

The unit of analysis in this study is the implicature recognized in sentences written in children's story book entitled Rumpelstiltskin based on Grice Maxim theory.

\section{Method of Data Collection}

The objects of the study are the words/phrases/sentences written in the children's story book entitled Rumpelstiltskin. The data collection in this study is gathered based on the following steps:

1. The researchers read the story

2. The researchers identified the data containing conversational implicature on the basis of Grice Maxims theory

\section{Method of Data Analysis}

The next step after collecting data is data analysis. The analysis is done using the following steps:

1. The identified data are categorized into Grice Maxims theory using different marks

2. The identified data are classified based on features and kinds of implicature

3. The classified data are interpreted using relevant theories supporting the analysis 
4. The interpretation is written in the narrative form using researcher's interpretative knowledge

\section{FIINDINGS}

The findings in this study are words/phrases/sentences containing conversational implicature based on Grice Maxims theory.

\section{Conversational implicature based on Grice Maxims:}

a. There are $20(41.67 \%)$ conversational implicature belongs to Maxims of Quality (Q1) because they meet the characteristic of maxims of quality those are telling the truth and believe that what has been told is true, for instances are:

Once, there was a poor Miller whose greatest treasure was his beautiful daughter it means that it is true that the poor Miller has a beautiful daughter who he admires and cares for.

The King loved gold more than anything else in the world. Everything in his castle was made of gold-the dishes, the tables, the royal flags, the swords, and even the horse's saddles it means that as the King he does not hide his true feeling of having gold as his treasure and he keeps it in his castle.

b. There are $18(37.5 \%)$ conversational implicature belongs to maxims of quantity (Q2) because they meet the characteristic of this maxims that is giving information as it is required and informative. For examples are:

Upon learning that the Miller's daughter could turn straw into gold, the King demanded to see her at once it means that this shows how the King is curious only by hearing the news about the Miller's daughter who can turn straw into gold.

She had no idea how to turn straw into gold till dawn. Her father had made up the whole story it shows that because of his father boasting that she could turn straw into gold made her really confused.

c. There are $4(8.33 \%)$ conversational implicature belongs to maxims of relevance because it meets the requirement for this maxims that is the speakers speak something relevant to their subject of communication. For examples are:

She had long, golden hair, eyes as blue as the deepest sea, and a warm, gentle smile it shows that the poor Miller described his daughter who is really beautiful metaphorically.

One day the Miller, hoping to win the King's favor, boasted that his daughter could spin straw into gold it means that this implicature shows the poor Miller's expectation to be rich by boasting that his daughter has magical power. 
d. There are $6(12.5 \%)$ conversational implicature belongs to maxims of manner because they meet the requirement for this maxims that is the speakers must say something orderly and briefly. For instances are:

When the Miller's daughter arrived at the castle, the King led her into a room filled with bundles of straw and a large spinning wheel, "You have to spin this straw into gold till dawn, "he said. "If there is any straw left when the sun rises, you will die." It means that the King ordered to miller's daughter orderly and briefly and even he threatened her if she failed what will happen to her.

"Cast your magic again, demanded the King, "Or you will die at sunrise." it shows that the King realized that the miller's daughter has magical power therefore he ordered her for another work to do.

\section{Features of context:}

The implicatures are then categorized into features of context namely setting (material; place and time), activity and relation as follows:

Setting is classified into material components, setting of place and time.

Material covers material components around language interactions such as the person involved as subjects, the verbs and the objects. The examples of subjects are: the King, the poor Miller, the Miller's daughter and the dwarf. The examples of objects are: the straw, the gold and the horse. The examples of verbs are: spin, demand, order, turn, etc.

Setting of place of this story covers at the castle, at the room, at the stable and at the straw hut.

Setting of time of this story covers once, now, the next day, etc.

Activity is all behavior happened through linguistic interaction such as hoping, loved, thinking, turning, weeping, etc.

Relation can be determined from the age, sex, social status, etc. and those are poor, rich, King, miller's daughter, son, etc.

\section{Kind of context:}

After the implicature are categorized into features of context then it was classified into kinds of context which is divided into physical context, linguistic context, social context and epistemic context as follows:

Physical context covers the place, the object and the act and they are:

the place: at the castle, in the room, at the stable

the object: straw, gold, horses

the act: turn, spin, ordered, demanded 
Linguistic context is speech events used in communication namely: statement, description and explanation.

Social context is social relation among the speakers and they are: the King, the poor miller, the miller's daughter, the queen, and the dwarf.

Epistemic context is concept of message found in the communication namely: giving information, describing, explaining and asking.

\section{CONCLUSIONS}

Based on the findings, the researchers can draw some conclusions as follows:

1. The story applied maxims of quality (41.67\%) because most of the story show the truth about the characters and things happened among them. This story is a narrative as it tells about imagery things. Though it is narrative but young readers can learn something that is helping them improve their vocabulary.

2. The features of context recognized in the story are the King, the miller's daughter and the dwarf. They are involved as the main characters. The activity is turning straw into gold as the wish of the king with magical power from the dwarf and the King's command for miller's daughter. The place is mainly occurred at the castle.

3. The kinds of contexts are physical context, linguistic context, social context and epistemic context. The main physical context is at the castle. The linguistic context is statement because most sentences are about stating about something. The social context is about the relationship between the King and miller's daughter and the epistemic context is about message that is giving information.

4. The young readers can learn some values from reading this story such as trustworthy, telling the truth, do not tell lies, feeling empathy, showing care, and helping others.

\section{REFERENCES}

COBUILD, Collins. 2015. Advanced Dictionary of English. Jakarta: Gramedia

Cummings, Louise. 2005. Pragmatics: A Multidiciplinary Perspective. Edinburg University Press.

Levinson, Stephen C. 2000. Pragmatics. London: Cambridge University Press.

Young Learner's Series of Story Books. -. Rumplestiltskin. Young Learner Publications: New Delhi 
Yule, George. 1996. Pragmatics. New York: Oxford University Press.

Kurnia Putri, Prillia. 2017. Implicature Analysis of Seven Slogans of Isotonic Beverage Product On The Online Advertisement (unpublished thesis of Faculty of Language and Cultural Studies, University of Stikubank, 2017).

http://www.academia.edu/29875281/Research_Methods_in_Linguistics._Litosseli

ti._Continuum._2010.pdf (Accessed on Nov 12, 2017, 10.00 a.m) 